\title{
平原农区村民居住空间特征与迁居意愿 一以江苏省淮安市为例
}

\author{
刘传明 ${ }^{1}$, 尚正永 ${ }^{2}$, 周洪英 ${ }^{1}$, 王呈祥 ${ }^{1}$, 蔡安宁 ${ }^{1}$
}

(1. 淮阴师范学院城市与环境学院, 淮安 $223300 ; 2$. 苏州科技大学环境科学与工程学院, 苏州 215009)

\begin{abstract}
摘要：选择地处苏北平原农区的淮安市所有 15510 个自然村和 872414 户农户全样本人户调查 数据为分析对象, 采用占比统计法和 GIS 空间分析, 对村民居住空间特征与迁居意愿进行研 究。主要结论如下: (1) 在村落层面, 平均规模小, 单村独户多且村落分散, 多数自然村远离镇 区,近一半自然村位居 “九靠近一滞洪” 区域内。该格局是自然地理条件和人文因素综合影响 形成的。(2)在住房层面, 农村老旧住房比例高, 全市 $40 \%$ 农户在城乡同时拥有住房, 但在城镇 拥有住房率与到城区距离呈负相关, 而农村住房空关率则呈现相反的空间格局。(3)在迁居意 愿方面, $54.1 \%$ 的农户愿意集中居住且多意向实物安置, 较低补偿标准和不便务农是不愿迁居 的主要原因; 移居城镇是货币安置农户的主要去向, 留村和人镇集中居住是实物安置农户的主 要去向。在迁居意向农户中, 近 $90 \%$ 选择政府统建方式, 近 $80 \%$ 愿意有偿退出宅基地和流转承 包地。(4)村民居住空间特征和迁居意愿都存在明显的空间差异, 两者之间存有内在联系且均 受多种因素影响。
\end{abstract}

关键词：居住空间特征;迁居意愿;全样本调查;平原农区;淮安市

在快速城镇化背景下，乡村衰落几乎是每个经历过工业化的国家在发展过程中必然 面临的问题 ${ }^{[1]}$ ，工业化和城镇化导致了村镇结构的消解和功能的衰落 ${ }^{[2,3]}$ 。我国传统村落出 现了解体与重构, “乡土中国” 快速向 “离土中国” [1]、“城市中国” ${ }^{[4]}$ 演替。在此背景 下, 乡村居住空间以及村民迁居等问题成为研究热点, 相关研究主题涉及乡村聚落地域 类型 ${ }^{[5]} 、 乡$ 村聚落空间重构 ${ }^{[6]}$ 、农村居民点整理 ${ }^{[1,8]}$ 、村民居住空间 ${ }^{[9]}$ 、村民集中居住意愿 ${ }^{[1]}$ 、 集中居住的影响因素 ${ }^{[10]}$ 、集中居住模式 ${ }^{[11-14]}$ 、乡村聚居调控和优化模式 ${ }^{[15,16]}$ 、村民集中居 住过程中的权益保障和利益主体博弯 ${ }^{[17,18]}$ 、乡村集中居住的发生机制 ${ }^{[1,20] 、}$ 、激励相容的制 度设计等 ${ }^{[21,2]}$ 。还有学者基于居住、生产、生态等乡村空间类型划分, 从社会经济转型与 乡村空间转型互动的角度, 对乡村空间重构进行整体研究 ${ }^{[23-25]}$ 。总之, 学术界在乡村居住 空间和迁居等领域已取得了较为丰富的研究成果，并呈现出单一类型空间向多种类型空 间、由地理空间向社会制度空间转变的研究趋势[1]。毫无疑问, 农民集中居住不仅带来乡 村聚落空间重构和人居环境的改善，同时也是节约农村居民点用地，保障耕地红线和增 加建设用地指标的有效途径 ${ }^{[26-28]}$ 。相对于山地丘陵地区农村，平原农区农民集中居住产生 的社会经济效益更加突出。因此，无论在社会主义新农村建设时期，还是在实施乡村振

收稿日期：2020-02-28; 修订日期：2020-05-28

基金项目：国家自然科学基金项目（41371171）；教育部人文社会科学基金项目（12YJCZH127）；江苏省社会科学基 金项目 (19GLB017)

作者简介: 刘传明 (1979- ), 男, 山东菏泽人, 博士, 副教授, 主要从事区域发展与城乡规划、聚落地理研究。 E-mail: Lcmdoc518@126.com

通讯作者：尚正永 (1968-), 男, 江苏淮阴人, 博士, 教授, 主要从事城乡发展与城乡规划研究。

E-mail: shangzy@usts.edu.cn 
兴战略，促进城乡融合发展中，地方政府对推进平原地区农民集中居住的热情和动力都 异常高涨 ${ }^{[29]}$ 。而农户居住空间的现状特征和迁居意愿调查分析是判断农户迁居有无现实 需求和能否顺利实施并取得预期成效的重要依据。现有相关文献 ${ }^{[11-14]}$ 多选择具体村落进行 “点状” 剖析或在 “面域” (省、市、县域) 尺度上进行抽样调查研究，而基于市县尺度 村落和农户全样本调查数据的研究尚未见到。

2018年，江苏省启动了加快苏北地区农民群众住房条件改善的工作，淮安市结合乡 村振战略实施在全市予以大力推动。为此, 淮安市统计部门对全市所有村落和农户进行 了全样本人户调查。而本文将利用本次调查数据, 对淮安市村民居住空间特征与迁居意 愿进行研究, 一方面可以增加乡村研究的典型案例, 另一方面可以弥补现有在面状尺度 上利用农户普查数据研究的不足。

\section{1 研究区概况与数据来源}

\section{1 研究区概况}

淮安市地处我国南北方地理过渡带, 位于江 苏省中北部，属黄淮平原和江淮平原，平原面积 占 $69.39 \%$, 市境西南部有少量丘陵岗地，全市河 湖水网众多, 水域面积占 $11.39 \%$ （图 1)。气候兼 具北亚热带湿润季风气候和北温带半湿润季风气 候特征, 农业生产条件优越, 是我国典型的平原 农区之一。2018年底, 全市总面积 $10030 \mathrm{~km}^{2}$, 现 辖清江浦区、淮安区、淮阴区、洪泽区、涟水 县、金湖县和盯眙县等四区三县, 共有 95 个乡镇 街道，1706个行政村（居）委会，15510个自然 村, 农村户籍人口 386.84 万人乡村, 常住人口 187.98 万人, 城镇化率 $62.44 \%$, 人均地区生产总 值 73204 元。淮安市历史上属于黄淮泛区, 洪涝 灾害频发, 水系水网多次变迁。村庄形成初期多 是村民自发选择地点, 后期发展多缺少规划引 导。2000年开始, 政府严控农村自建住房。目

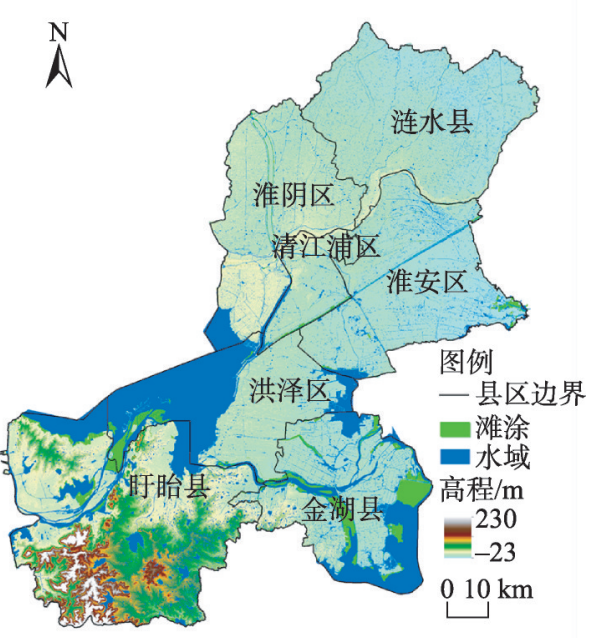

图 1 研究区位置与地势高程图

Fig. 1 Location and elevation map of the study area 前，全市农户空关率将近 $20 \%$, “空心村” “老人村” 较为普遍。全市绝大多数村庄没 有特色，仅有 1 个 “中国传统村落”、8个 “全国文明村” 和正在建设的 80 个美丽乡村与 17 个田园综合体。

\section{2 数据来源}

本文中淮安市村庄和农户调查数据主要为淮安市统计局于 2018 年 10 月到 11 月期间 组织的全样本人户调查数据, 调查对象包括全市 15510 个自然村 872414 户农户, 调查内 容包括村庄特色、村庄地理区位环境、村庄农户情况、村民集中居住意愿、村民土地和 宅基地流转意愿等。文中有关全国、江苏省和淮安市面上数据来源于《中国统计年鉴 （2019）》《中国城乡建设统计年鉴（2017）》《江苏统计年鉴（2019）》《淮安统计年鉴 （2019）》。村庄地理空间数据来源于全国基础地理信息和淮安市第二次土地调查数据。 


\section{2 结果分析}

\section{1 村民居住空间特征}

\section{1 .1 居住村落特征与形成机制}

（1）自然村密度大,空间分异明显

淮安市自然村密度高达 1.546 个 $/ \mathrm{km}^{2}$ ，是全国自然村密度 $\left(0.254\right.$ 个 $\left./ \mathrm{km}^{2}\right)$ 的 6 倍，也 远高于江苏省自然村分布密度 $\left(1.203\right.$ 个 $\left./ \mathrm{km}^{2}\right)$ 。就自然村规模而言，平均每个自然村仅 为 56.26 户，约 240 余人，小于全国自然村平均规模（253.51人个）。不仅如此，自然村 中分散居住和单庄独户数量也较高。其中，10人以下村庄的分散居住户为 37291 户，单 庄独户有 4267 户，村落分散特征明显。

自然村数量、乡村人口、农户居住情况等指标在县区尺度上存在明显差异（表 1$)$ ， 如涟水县农户家庭规模平均为 4.6 人，而金湖县仅为 3.4 人； 10 户以下村庄的分散居住户 以盯眙县为最多，其丘陵地形是决定性影响因素；清江浦区单庄独户率仅为 $0.01 \%$, 金 湖县却高达 $1.60 \%$ ，这是因为清江浦区农户都处在主城区近郊，用地管理较为严格，而 金湖县为远郊县且水网密度较高的缘故。另外，自然村分布和乡村人口密度在地理空间 分布上也存在非常明显的分异现象。具体而言，淮安市自然村表现出南北两大密集区、近 城区环状密集带和沿河沿路密集带、其他区域相对稀疏的空间格局（图 2a）。基于行政村 尺度的人口密度总体上则具有北高南低的空间特征，尤其是西南部低山丘陵区行政村人口 密度大多不足 200 人 $/ \mathrm{km}^{2}$, 而北部水网相对稀疏的平原地区人口密度呈现高值区（图 $2 \mathrm{~b}$ ）。

\section{表 1 淮安市自然村与乡村人口分布情况}

Table 1 Distribution of rural population and natural villages in Huai'an

\begin{tabular}{|c|c|c|c|c|c|c|c|c|c|c|}
\hline & \multirow{2}{*}{$\begin{array}{c}\text { 自然村 } \\
\text { /个 }\end{array}$} & \multirow{2}{*}{ 户数/户 } & \multirow{2}{*}{$\begin{array}{c}\text { 户籍人口 } \\
\text { /人 }\end{array}$} & \multirow{2}{*}{$\begin{array}{c}\text { 户均人口 } \\
\text { /(人/户 })\end{array}$} & \multicolumn{2}{|c|}{ 全家外出户 } & \multicolumn{2}{|c|}{ 分散居住 } & \multicolumn{2}{|c|}{ 单庄独户 } \\
\hline & & & & & 户数/户 & 百分比 $/ \%$ & 户数/户 & 百分比 $/ \%$ & 户数/户 & 百分比 $/ \%$ \\
\hline 清江浦区 & 382 & 25563 & 114449 & 4.5 & 1361 & 5.32 & 497 & 1.94 & 2 & 0.01 \\
\hline 淮安区 & 3245 & 223384 & 954968 & 4.3 & 24049 & 10.77 & 4283 & 1.92 & 454 & 0.20 \\
\hline 淮阴区 & 2616 & 148424 & 648438 & 4.4 & 13421 & 9.04 & 7982 & 5.38 & 915 & 0.62 \\
\hline 洪泽区 & 1007 & 52107 & 209211 & 4.0 & 7253 & 13.92 & 2580 & 4.95 & 228 & 0.44 \\
\hline 涟水县 & 4118 & 220003 & 1015966 & 4.6 & 28585 & 12.99 & 7756 & 3.53 & 823 & 0.37 \\
\hline 䀒眙县 & 2519 & 123438 & 536219 & 4.3 & 19540 & 15.83 & 10374 & 8.40 & 740 & 0.60 \\
\hline 金湖县 & 1623 & 64726 & 222248 & 3.4 & 5777 & 8.93 & 3024 & 4.67 & 1034 & 1.60 \\
\hline 淮安市 & 15510 & 872414 & 3768420 & 4.3 & 100883 & 11.56 & 37291 & 4.27 & 4267 & 0.49 \\
\hline
\end{tabular}

(2)多数自然村远离集镇,经济区位条件差

全市 $80 \%$ 的自然村距离镇区在 $2 \mathrm{~km}$ 以上，超过 $40 \%$ 的自然村距离镇区 $5 \mathrm{~km}$ 以上, $15.47 \%$ 的自然村到镇区距离超过 $10 \mathrm{~km}$ ，仅有不到 $20 \%$ 的自然村位于镇区 $2 \mathrm{~km}$ 范围内 （图3、图4）。自然村远离集镇的空间分布特征，不仅反映乡村聚落的积聚性不足，也直接 导致自然村较劣的经济区位条件，并制约镇区中心地职能的发挥和城镇建设水平的提高。

自然村与镇区的区位关系同样存在明显的县区差异（图 3)。从相对数来看，自然村 到镇区距离在 $2 \mathrm{~km}$ 以内、2 5 km、5 10 km 和 $10 \mathrm{~km}$ 以上范围的占比最高的分别是清江 浦区的 $32.20 \%$ 、涟水县的 $43.98 \%$ 、金湖县的 $36.87 \%$ 和䀒眙县的 $30.45 \%$ 。总体而言，清 

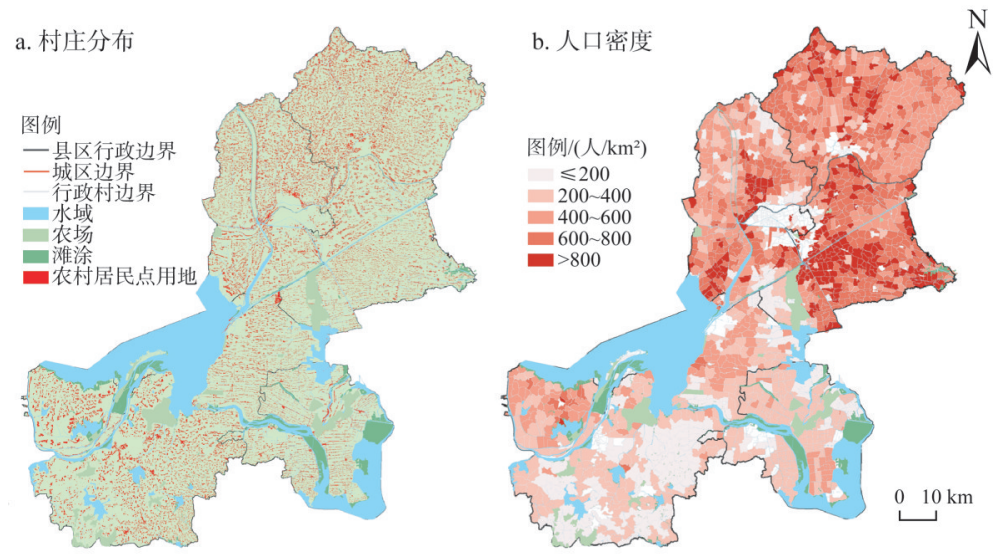

图 2 淮安市村落与乡村人口密度分布

Fig. 2 Spatial distribution of rural settlements and population density in Huaian

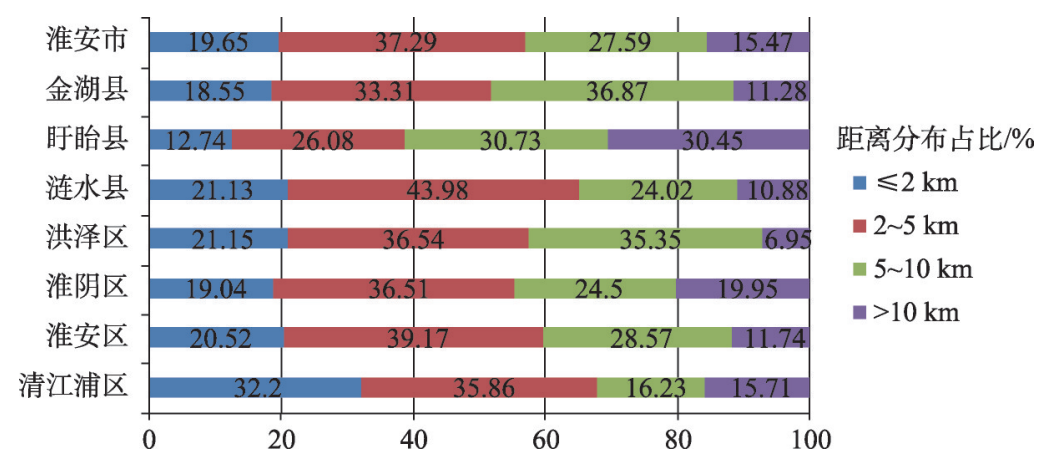

图 3 淮安市自然村到镇区距离分布占比统计

Fig. 3 Percentage of different distances from natural villages to towns in Huai'an

江浦区有 $68.06 \%$ 的自然村与集镇的距离在 $5 \mathrm{~km}$ 以 内，盱眙县则有 $61.18 \%$ 的自然村庄到集镇的空间 距离在 $5 \mathrm{~km}$ 以上。

(3)近半数自然村位居 “九靠近一滞洪” 区域 内,不利于村落发展

通过调查自然村 $500 \mathrm{~m}$ 范围内地理区位环境 (图 5), 可以发现：全市有 $44.10 \%$ 自然村位于 “九靠近一滞洪” 区域内，其中 2311 个村庄兼具 “九靠近一滞洪” 的两种以上情况。虽然靠近生态 红线或水源地能给村落带来良好的自然环境或自 然风光，但在促进村落发展方面更多的是弊大于 利。通常情况下，“九靠近一滞洪” 区域对村落基 本上以负面影响为主, 要么是大气或噪音污染 （靠近污染源、化工园、铁路、机场、高速公路、 内河航道等), 要么是限制乡村发展 (靠近水源

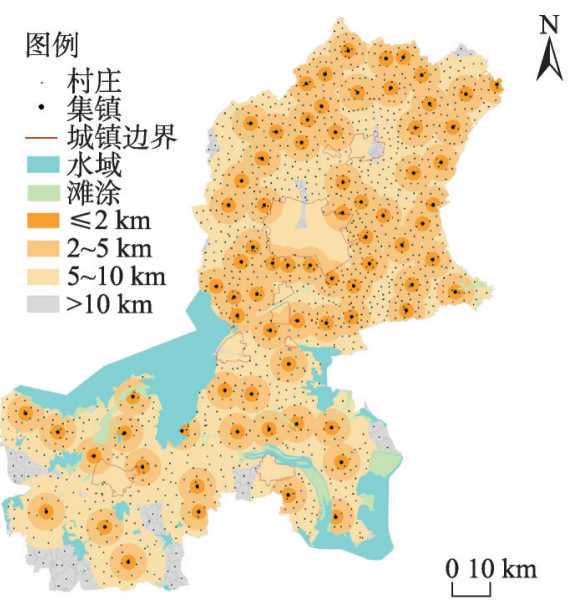

图 4 淮安市集镇不同服务半径内 行政村分布

Fig. 4 Administrative village distribution in different service radiuses of township in Huai'an 
地、生态红线、油气（卤水）管道、蓄滞 洪区等)。因此，淮安市近半数自然村发展 的地理环境条件较差。

(4)村落特征的形成机制

淮安市村落密布、平均规模小和多数 村庄区位条件劣的空间格局形成，既有自 然条件基础也有社会经济发展推动, 是多 种因素综合作用形成的。但不可否认，河 网众多、水灾频发和部分地形破碎是早期 村落分散格局形成的决定性因素，在此基 础上人口迁人与增长、道路条件改变、缺

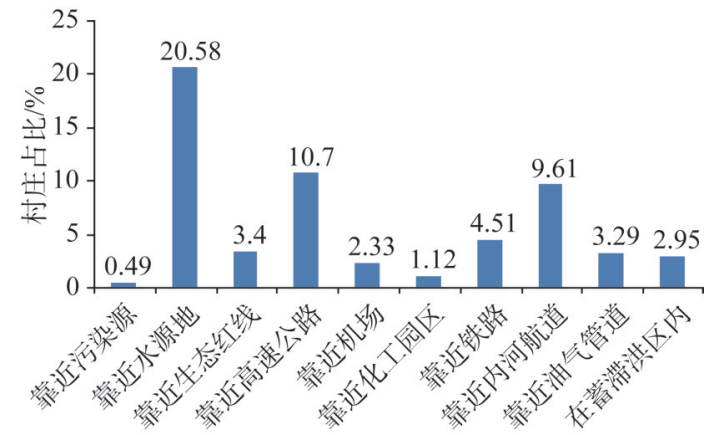

图 5 淮安市自然村地理区位环境

Fig. 5 Geographical location of natural villages in Huai'an 少管控和多轮撤乡并镇等人文因素进一步加剧了分散格局。其形成机制过程见图 6 。

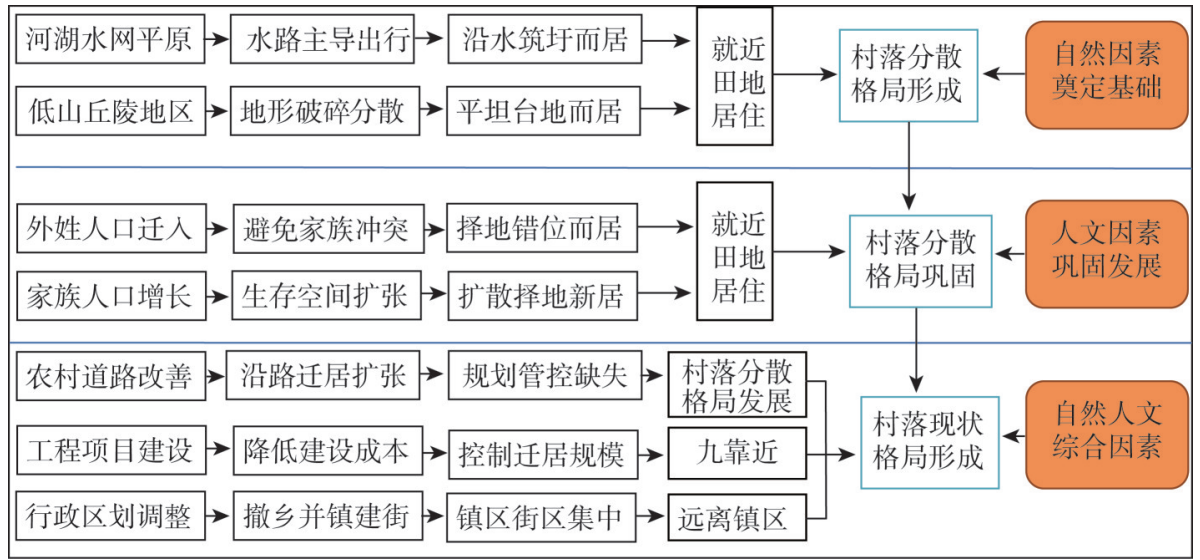

图 6 村落空间特征形成与演变机制

Fig. 6 The formation and evolution mechanism of village spatial characteristics

\section{1 .2 农户居住房屋特征}

(1)四成农户同时拥有城乡住房,城镇住房拥有率与到城区距离呈反相关

据调查，淮安全市在本村拥有住房的农户占 $97.0 \%, 43.9 \%$ 的农户在城镇拥有住房， 由此可见约有 $40 \%$ 农户在农村和城镇同时拥有住房。这也反映了城镇化的潜力。

从图 $7 \mathrm{~b}$ 可见，不同村庄村民在城镇拥有住房率存在明显的差异，拥有率的高低与到 城区（包括主城区、县城）距离呈反相关。具体而言，距离城区越近的村庄农户在本村 拥有住房的比例越高，而在城镇拥有住房的比例越低。这与城区近郊村民有保留农村住 宅等待城乡建设拓展获取拆迁补偿心态不无关系。另一方面，近郊村民生活较为便利， 能够容易获得城市的相关公共服务，因此也不急于在城区购房居住，而是更注重未来拆 迁的预期经济收益。

从农户已购城镇住房的宏观区位分布看（表 2)，全市已购城镇住房的农户约有 52\% 选择在市区和县城，约 $30 \%$ 选择在现政府驻地镇区和原政府驻地镇区购房，只有不到 18\%农户选择在淮安市之外的城镇购房。另外，可以发现在市区购房的主要是主城区郊 区和近主城区的淮阴区和淮安区农户（两区城区与主城区在空间上连成一体），而远离主 


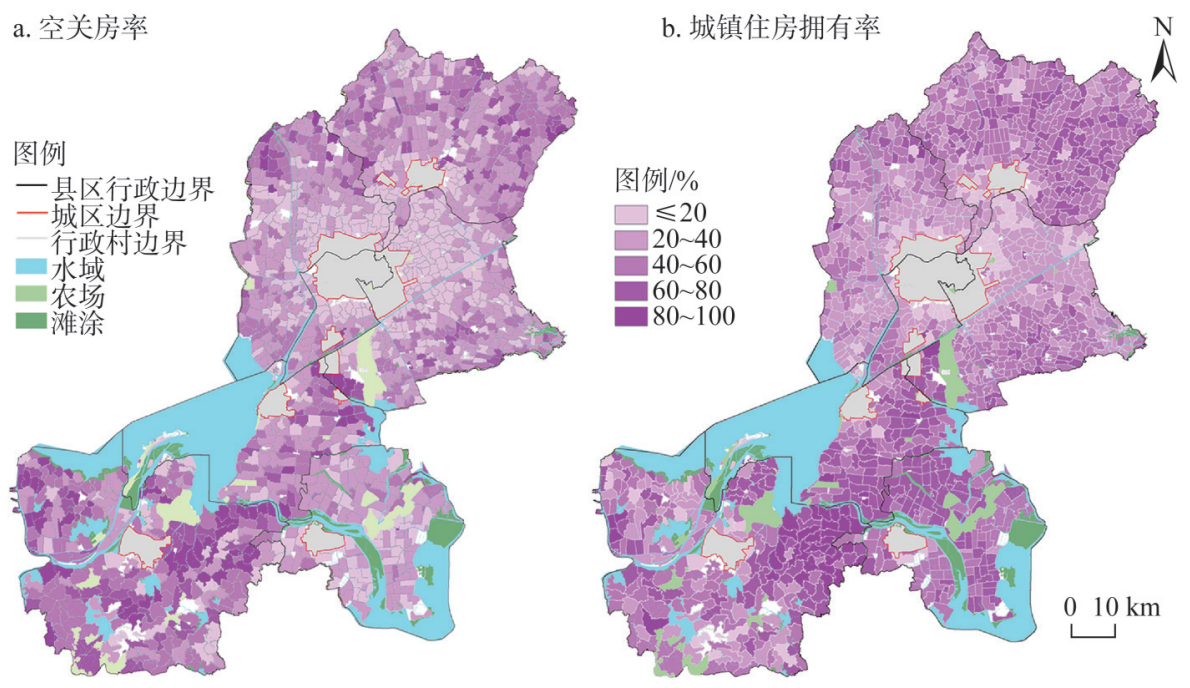

图 7 农户空关房率与城镇住房拥有率空间分布

Fig. 7 The spatial distribution of the rates of unoccupied or closed rural houses and owning houses in towns

表 2 农户在城镇拥有房屋情况

Table 2 Farmer household owning houses in cities and towns

\begin{tabular}{|c|c|c|c|c|c|c|c|}
\hline \multirow{2}{*}{ 指标名称 } & \multicolumn{2}{|c|}{ 在城镇有房户 } & \multicolumn{5}{|c|}{ 城镇房屋位置占比/\% } \\
\hline & 数量/户 & 占比/\% & 现政府驻地镇区 & 原政府驻地镇区 & 县城 & 市主城区 & 外地城镇 \\
\hline 清江浦区 & 7953 & 31.1 & 17.6 & 5.4 & 2.3 & 66.9 & 7.8 \\
\hline 淮安区 & 83040 & 37.2 & 15.9 & 7.8 & 29.3 & 12.5 & 34.5 \\
\hline 淮阴区 & 51822 & 34.9 & 18.1 & 10.6 & 35.9 & 24.0 & 11.5 \\
\hline 洪泽区 & 30144 & 57.9 & 15.5 & 5.7 & 53.8 & 6.1 & 18.9 \\
\hline 涟水县 & 105680 & 48.0 & 20.5 & 5.5 & 51.0 & 8.9 & 14.2 \\
\hline 盱眙县 & 63591 & 51.5 & 41.8 & 17.7 & 28.5 & 1.9 & 10.1 \\
\hline 金湖县 & 37804 & 58.4 & 9.5 & 5.9 & 67.8 & 2.1 & 14.6 \\
\hline 淮安市 & 383018 & 43.9 & 21.3 & 8.8 & 41.1 & 11.0 & 17.8 \\
\hline
\end{tabular}

城区的洪泽区、䀒眙县、金湖县和涟水县在淮安市区购房的比例明显低于全市平均水 平，尤其是距离更远的旰眙和金湖二县在市区购房率仅为 $2 \%$ 左右。毫无疑问，造成此现 象的主要原因是距离因素。另外，淮安区在外地城镇购房户占到 $34.5 \%$, 远高于全市平 均水平和其他县区, 这主要是因为淮安区具有悠久的经商传统、多数村民具有做生意观 念、在全国各地经商者较多的缘故。

(2)农村住房空关率较高,自城区向远郊呈递增趋势

淮安全市农村空关户有 141898 户，占 $16.8 \%$, 村庄空心化现象普遍存在。这与前述 全市约 $40 \%$ 的农户在城乡同时拥有住房存在直接因果关系。并以此预见，随着城镇化推 进，农村空心化仍有很大增长空间。同时，农村房屋的高空关率和城镇住房的高拥有 率，也很好地解释了前述淮安市农村户籍人口数（386.84万人）与常住人口数（187.98 万人）之间的巨大差异现象。

另外，农村住房空关率在空间上不仅呈现出自城区向远郊递增的规律（图 7a)，而且 
各县区之间也存在明显差异（图 8)。其 中, 盱眙县空关率为全市最高, 达 $27.4 \%$, 主要原因是䀒眙县丘陵山地的地形条件使得 自然村较为分散, 交通多有不便, 在城镇购 买住房的农户有 $41.8 \%$ 选择在了当地镇区居 住, 这一比例远高于其他县区, 该部分农户 在本村的住房就失去了其使用价值, 必然是 空置状态。

(3)农村住房质量参差不齐, 老旧房屋比 例较高

据实地访谈和相关文献，淮安市农村住

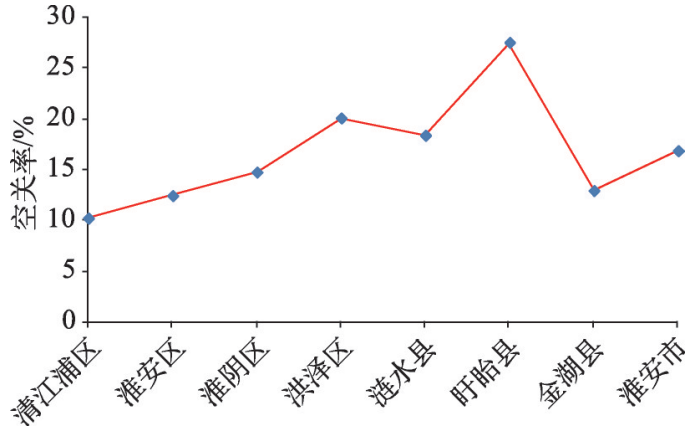

图 8 淮安市各县区农村住房空关率

Fig. 8 The rates of unoccupied or closed rural houses in different counties of Huai'an 房和苏北多数农村一样大致经过了四代更新

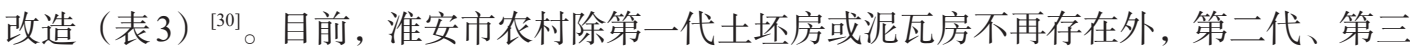
代和第四代房屋同时存在。就房屋质量和房龄来看（表4），全市有房的农户中反映房屋 质量较差的有 211380 户，占 $25.0 \%$ 。20 年以上房龄住房占 $67.2 \%$ ，其中 30 年以上房龄占 $26.5 \% ； 20$ 年以下房龄的房屋仅占 $32.8 \%$ 。这与 2000 年之后，政府推行严格控制农民自 建住房的政策有直接关系。

\section{表 3 淮安市农村住房发展的代际划分与特征}

Table 3 Intergenerational division and characteristics of rural housing development in Huai'an

\begin{tabular}{|c|c|c|}
\hline 代际划分 & 类型 & 主要特征 \\
\hline $\begin{array}{l}\text { 第一代 } \\
\text { (1980年代前) }\end{array}$ & $\begin{array}{l}\text { 土坏房 } \\
\text { 泥瓦房 }\end{array}$ & $\begin{array}{l}\text { 建筑材料为土坯、草或瓦房, 房屋为一层。该类农房功能单一, 缺乏私密空间, } \\
\text { 抗震、抗风等抗击自然灾害的能力差 }\end{array}$ \\
\hline $\begin{array}{l}\text { 第二代 } \\
\text { (1980-2000年) }\end{array}$ & 砖瓦房 & $\begin{array}{l}\text { 砖混结构, 墙面是砖, 房顶是瓦, 房屋为一层。该类农房较为坚固, 抗震、抗风 } \\
\text { 等抗击自然灾害的能力大幅度提高 }\end{array}$ \\
\hline $\begin{array}{l}\text { 第三代 } \\
(2000-2010 \text { 年) }\end{array}$ & 经济型楼房 & $\begin{array}{l}\text { 楼房为两层或两层以上, 钢混结构, 独栋或联排布局。采光、通风、居住私密性 } \\
\text { 良好, 功能比较完善。抗击自然灾害的能力强。农房经济实惠, 注重实用, 不重 } \\
\text { 视房屋外观装饰和人居环境营造 }\end{array}$ \\
\hline $\begin{array}{l}\text { 第四代 } \\
\text { (2010年以后) }\end{array}$ & 高质量楼房 & $\begin{array}{l}\text { 为两层或两层以上, 钢混结构, 独门独院, 私密性好, 有庭院和车库。一般独栋 } \\
\text { 或联排布局, 有统一的平面设计, 抗震、抗风等抗击自然灾害的能力强, 注重房 } \\
\text { 屋外观装饰和人居环境营造 }\end{array}$ \\
\hline
\end{tabular}

表 4 淮安市农户房屋质量情况

Table 4 The housing quality of farmers in Huai'an

\begin{tabular}{ccccccc}
\hline & $\begin{array}{c}\text { 自认质量 } \\
\text { 较差 } / \%\end{array}$ & $\begin{array}{c}30 \text { 年以上 } \\
\text { 房龄 } \%\end{array}$ & $\begin{array}{c}20 \sim 30 \text { 年 } \\
\text { 房龄 } \%\end{array}$ & $\begin{array}{c}20 \text { 年以下 } \\
\text { 房龄 } / \%\end{array}$ & $\begin{array}{c}\text { 户均面积 } \\
/\left(\mathrm{m}^{2} / \text { 户 }\right)\end{array}$ & $\begin{array}{c}\text { 楼房 } \\
\text { 占比 } / \%\end{array}$ \\
\hline 清江浦区 & 10.9 & 9.7 & 20.8 & 69.5 & 295 & 83.8 \\
淮安区 & 22.7 & 19.6 & 37.8 & 42.6 & 190 & 62.8 \\
淮阴区 & 21.6 & 22 & 39.3 & 38.7 & 214 & 56.0 \\
洪泽区 & 38.3 & 42.4 & 43.8 & 13.7 & 137 & 22.2 \\
涟水县 & 22.7 & 32.2 & 44.8 & 23 & 175 & 41.6 \\
盯眙县 & 31.7 & 30.4 & 44.5 & 25.1 & 146 & 25.3 \\
金湖县 & 30.6 & 31.1 & 37.7 & 31.1 & 136 & 23.2 \\
淮安市 & 25.0 & 26.5 & 40.7 & 32.8 & 181 & 46.3 \\
\hline
\end{tabular}


各县区农村房屋质量存在明显的空间差异：有房农户中反映房屋质量较差占比最高 的是洪泽区，占 $38.3 \%$ ，远高于全市 $25.0 \%$ 的平均水平。 30 年以上房龄房屋占比最高的为 清江浦区，比例高达 $69.5 \%$ ，远高于全市平均水平的 $32.8 \%$ 。这也反映了主城区近郊限制 农民自建房屋政策实施时间要早于其他县区，执行力度也大于其他县区。

(4)县区户均房屋面积和楼房比例差异巨大,呈“北高南低”空间格局

全市农村房屋户均面积 $181 \mathrm{~m}^{2}$ ，在分布上呈现 “北高南低” 的特点（表4）。北部清 江浦区、淮安区、淮阴区、涟水县户均房屋建筑面积分别为 $295 \mathrm{~m}^{2} 、 190 \mathrm{~m}^{2} 、 214 \mathrm{~m}^{2}$ 、 $175 \mathrm{~m}^{2}$, 而南部洪泽区、䀒眙县、金湖县户均房屋建筑面积分别为 $137 \mathrm{~m}^{2} 、 146 \mathrm{~m}^{2} 、 136 \mathrm{~m}^{2}$ 。 全市 84.62 万户有房农户中，楼房户有 39.20 万户，占 $46.3 \%$ 。其中，清江浦区楼房户占 比高达 $83.8 \%$ ，淮安区与淮阴区的楼房比例也分别高达 $62.8 \%$ 与 $56.0 \%$ ，表明农村居民居 住条件最好; 洪泽区、金湖县和䀒眙县的楼房比例分别为 $22.2 \% 、 23.5 \%$ 和 $25.3 \%$ ，比例 较低，表明农村居民的住房条件相对较差。

\section{2 农户迁居意愿与安置意向特征}

\section{2 .1 过半农户有集中居住意愿且多意向实物安置}

全市愿意迁居的农户共 471842 户，占总户数的 $54.1 \%$ （图 9)。而在愿意搬迁集中居 住的农户中，意向选择实物安置的占比为 $64.1 \%$ ，意向选择货币安置的占 $35.9 \%$ 。就安置 意向的县区差异看，愿意货币安置比例最高的是䀒眙县，占比达到 $73.6 \%$ 。愿意实物安 置的比例最高是的清江浦区，高达 $96.7 \%$, 其次是洪泽区，意向实物安置占比为 $81.1 \%$, 淮阴、淮安两区的占比相当分别为 $77.7 \%$ 、 $77.3 \%$, 金湖、涟水两县的占比也分别达到了 $68.3 \%$ 、62.9\%。同时，图 10 可以发现距主城区越近的农户越倾向于实物安置，其背后原 因是农户对实物安置增值预期要高于货币化安置。

影响不愿意搬迁集中居住的原因也不尽相同（图 11）。其中，补偿标准低是最主要原 因，不愿意集中居住的农户中约有 $72.8 \%$ 持该种观点。而因乡土观念较重，在本地时间 久不想离开的占到 $34.0 \%$ ；觉得集中后务农不便 的也超过了 $30 \%$ 。认为新房子没有自留地生活成 本低的占 $27.4 \%$ 。可以认为，上述四个方面构成 了不愿意搬迁集中居住的主要原因。而担忧生活 方式不习惯和其他原因占比较低，分别仅占 $12.6 \%$ 和 $1.7 \%$ 。由此可见，按照市场原则进行拆 迁补偿和改变农村散户经营农业生产方式为规模 化经营农业生产方式, 是治理农村住房空心化、 促进村民迁居的有效途径。

\subsection{2 不同安置方式意向农户迁居去向存在差异}

如前所述，货币安置和实物安置是村民搬迁 集中居住的两种安置方式。但两种安置方式下, 村民的迁居去向存在明显差异。

(1)意向货币安置农户的迁居去向

在全市具有货币安置意向的农户中（表 5), $41.5 \%$ 农户选择自行去城镇或外地购房, 反映了该

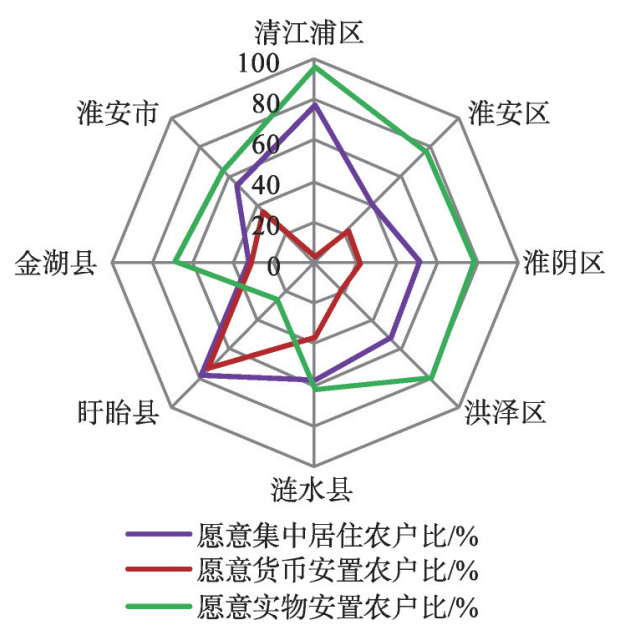

图 9 淮安市各县区农户集中居住 意愿及安置方式选择

Fig. 9 Farmer household resettlement willingness and placement mode selection among different counties in Huai'an 

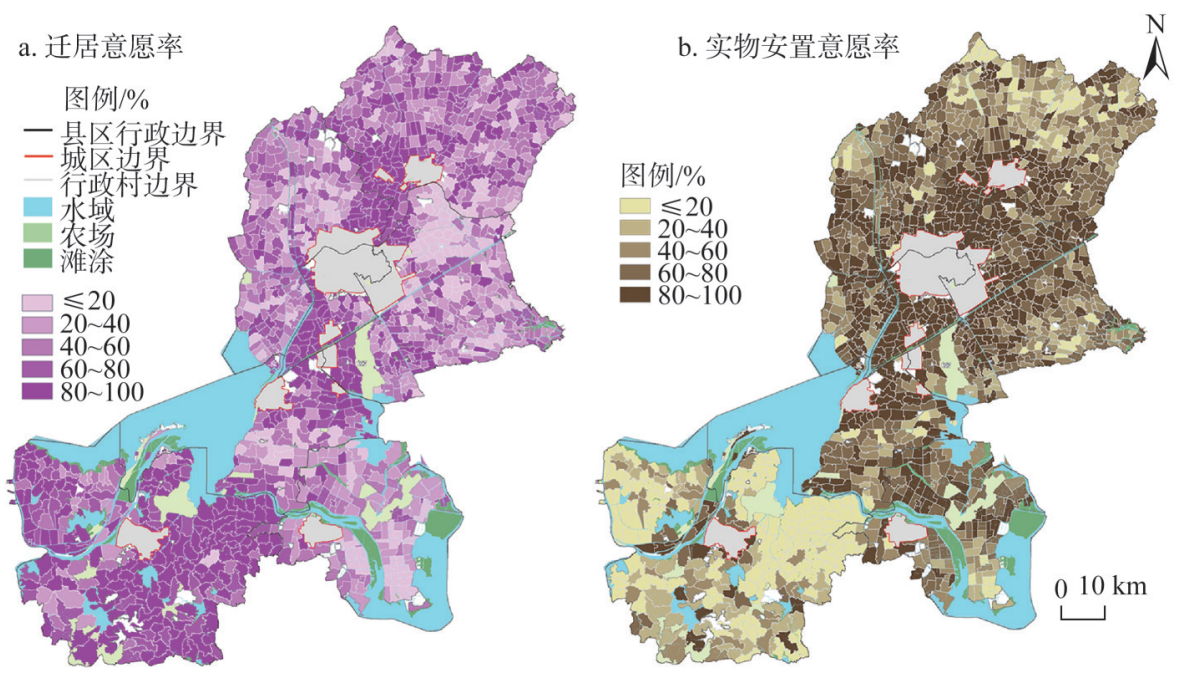

图 10 村域尺度的农户迁居与实物安置方式意愿

Fig. 10 Farmer household relocation and physical resettlement willingness by village scale

群体是推动城镇化进程的潜力股。有 $52.0 \%$ 农户 选择到自有房屋居住, 计划与子女（父母）同住 的仅占 $6.5 \%$ 。从各县区来看, 意向到城镇或外地 购房的占比最高的是淮阴区，为 $45.3 \%$ ，这与淮 阴区紧邻主城区的地理位置有密切关系; 占比最 低的是远离主城区的金湖县，仅为 $19.5 \%$ 。意向 到自有房屋居住占比最高的是清江浦区，为 $54.2 \%$ ，最低是仍是金湖县，为 $19.5 \%$ 。意向与子 女 (父母) 同住占比最高的是金湖县, 为 $16.0 \%$ 。

(2)意向实物安置农户的迁居去向

在全市选择实物安置的农户中（表 5), 有

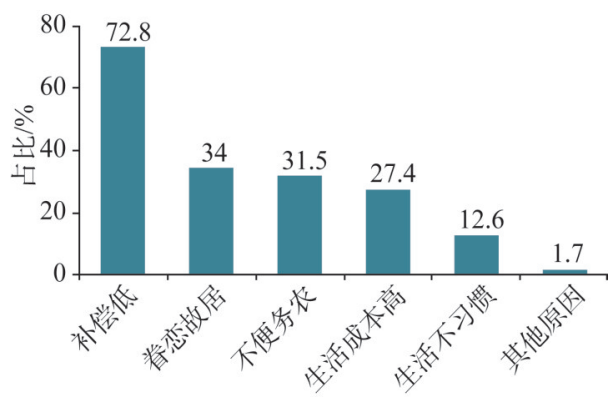

图 11 农户不愿意集中居住的原因

Fig. 11 Reasons for farmers' unwillingness to live together 92.8\%的农户选择在乡镇或村规划安置点集中居住，其中 $50.7 \%$ 农户选择在乡镇安置点。

表 5 货币安置与实物安置意向农户的迁居去向比较

Table 5 The comparison of farmers' willingness to relocation between monetary resettlements and physical resettlements (\%)

\begin{tabular}{|c|c|c|c|c|c|c|}
\hline & \multicolumn{3}{|c|}{ 货币安置意向农户迁居去向占比 } & \multicolumn{3}{|c|}{ 实物安置意向农户迁居去向占比 } \\
\hline & $\begin{array}{c}\text { 自行去城镇或 } \\
\text { 外地购房 }\end{array}$ & $\begin{array}{c}\text { 到自有 } \\
\text { 房屋居住 }\end{array}$ & $\begin{array}{c}\text { 与子女（父母） } \\
\text { 同住 }\end{array}$ & 乡镇安置点 & $\begin{array}{l}\text { 村规划 } \\
\text { 安置点 }\end{array}$ & 其他 \\
\hline 清江浦区 & 54.2 & 54.2 & 7.1 & 82.1 & 14.0 & 3.9 \\
\hline 淮安区 & 35.7 & 35.7 & 8.8 & 46.9 & 50.3 & 2.7 \\
\hline 淮阴区 & 45.3 & 45.3 & 6.0 & 59.7 & 29.2 & 11.1 \\
\hline 洪泽区 & 31.3 & 31.3 & 7.6 & 41.2 & 37.5 & 21.3 \\
\hline 涟水县 & 45.8 & 45.8 & 5.6 & 39.7 & 58.8 & 1.4 \\
\hline 盱眙县 & 42.0 & 42.0 & 5.6 & 44.3 & 53.1 & 2.6 \\
\hline 金湖县 & 19.5 & 19.5 & 16.0 & 49.9 & 18.9 & 31.2 \\
\hline 淮安市 & 41.5 & 52.0 & 6.5 & 50.7 & 42.1 & 7.2 \\
\hline
\end{tabular}


可见, 就近在乡镇安置点进行集中居住是多数农户的选择。从县区情况看, 意向到乡镇 安置点居住的农户占比最高的是清江浦区，达到 $82.1 \%$, 最低的是涟水县，为 $39.7 \%$ 。意 向到村规划安置点居住的占比最高的是涟水县, 为 $58.8 \%$; 最低的是清江浦区, 为 $14.0 \%$ ，金湖县有 $31.2 \%$ 的农户选择其他安置点居住。

2.2.3 意向实物安置农户的房屋选择特征

(1) 意向一套 80 150 $\mathrm{m}^{2}$ 安置房农户占据主体地位

就安置房套数选择而言，在全市实物安置意向农户中（表 6)，选择一套集中安置房 的占 $63.6 \%$, 需要两套的占 $22.7 \%$, 选择两套以上的占 $13.7 \%$, 说明意向一套安置住房的 农户占主体。从县区情况看，套数选择有明显的两极分化现象。其中，金湖县 $94.0 \%$ 的 农户选择一套住房, 这主要缘于金湖县平均家庭规模较小 ( 3.4 人/户), 并且远离主城区 选择多套房安置既无现实居住需求又无投资增值潜力。清江浦区农户在安置房套数选择 上则与金湖县截然不同，其中选择一套住房的仅为 $15.1 \%$ ，而选择两套以上住房的却高 达 $50.1 \%$ 。这说明清江浦区农户紧邻主城区，对未来拆迁安置预期要明显高于其他县区。

就安置房户型面积选择意向而言，在全市有实物安置意向的农户中，78.3\%的农户选 择 $80 \sim 150 \mathrm{~m}^{2}$ 住房，选择 $80 \mathrm{~m}^{2}$ 以下和 $150 \mathrm{~m}^{2}$ 以上的占比基本相同，分别为 $10.8 \%$ 和 $10.9 \%$ 。从县区来看, 各个县区有实物安置意向的农户选择 $80 \sim 150 \mathrm{~m}^{2}$ 住房的占比都比较 高，均在 $70 \%$ 以上，最高的是清江浦区为 $89.1 \%$ ，最低的是盯眙县为 $73.6 \%$ 。可见， $80 \sim$ $150 \mathrm{~m}^{2}$ 住房是实物安置农户的主流选择（表6）。

表 6 实物安置意向农户房屋套数与户型面积选择

Table 6 The choice about the number and unit size of resettlement houses for physical resettlement farmers

$(\%)$

\begin{tabular}{|c|c|c|c|c|c|c|}
\hline & \multicolumn{3}{|c|}{ 选择不同套数农户占比 } & \multicolumn{3}{|c|}{ 选择不同户型面积农户占比 } \\
\hline & 一套 & 两套 & 两套以上 & $80 \mathrm{~m}^{2}$ 以下 & $80 \sim 150 \mathrm{~m}^{2}$ & $150 \mathrm{~m}^{2}$ 以上 \\
\hline 清江浦区 & 15.1 & 34.9 & 50.1 & 3.4 & 89.1 & 7.5 \\
\hline 淮安区 & 67.3 & 22.3 & 10.4 & 11.2 & 76.3 & 12.5 \\
\hline 淮阴区 & 59.2 & 26.4 & 14.4 & 13.0 & 79.0 & 8.0 \\
\hline 洪泽区 & 75.0 & 21.1 & 3.9 & 11.1 & 79.2 & 9.7 \\
\hline 涟水县 & 70.7 & 22.4 & 6.9 & 11.1 & 77.8 & 11.1 \\
\hline 盱眙县 & 77.7 & 19.6 & 2.7 & 13.6 & 73.6 & 12.8 \\
\hline 金湖县 & 94.0 & 5.6 & 0.4 & 9.7 & 82.3 & 8.0 \\
\hline 淮安市 & 63.6 & 22.7 & 13.7 & 10.8 & 78.3 & 10.9 \\
\hline
\end{tabular}

(2)近九成实物安置意向农户选择由政府统建安置房

由图 12 可见，全市 $89.4 \%$ 实物安置意向农户希望由政府统建安置房屋，仅有 $10.6 \%$ 希望政府统一规划自己建设。各县区中希望由政府统建安置房屋的农户占比普遍较高, 清江浦区、淮安区、淮阴区、洪泽区、金湖县的占比都超过 $90 \%$, 䀒眙县最低也达到了 $73.2 \%$ 。可见，政府的信誉是推动农民集中居住和改善居住环境的最主要保障。

\subsection{4 意向迁居村民对土地流转的态度}

(1)愿迁农户对宅基地的处置意向

据统计，全市愿意搬迁集中居住的农户宅基地总面积达到 35521 万 $\mathrm{m}^{2}$ ，户均 $407 \mathrm{~m}^{2}$ 。搬迁后对宅基地整理的潜力巨大。其中，全市意向迁居农户中 $79.2 \%$ 愿意有偿 
退出宅基地, 盯眙县愿意有偿退出宅基地的农户 占比更是高达 $96.6 \%$, 位居全市第一（表 7)。这 与前述分析盯眙县农村住房空关率和在镇政府驻 地拥有住房率均位居全市第一的结论保持高度一 致。金湖县愿意有偿退出宅基地的农户占比虽然 最低，但也达到 $56.3 \%$ 。这与前述金湖县意向迁 居实物安置农户中选择一套房比例最高的分析结 论保持一致, 即意向迁居只要一套房但又尽可能 保留宅基地，从而实现自身利益最大化。

(2)愿迁农户对承包地的处置意向

全市愿迁农户中 $78.6 \%$ 有意流转承包地， $11.9 \%$ 愿意继续自己经营, $5.1 \%$ 愿意退出, 仅

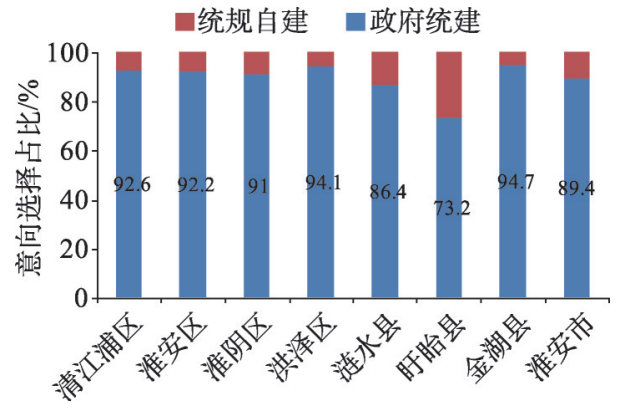

图 12 农户集中居住安置房建设 方式意向选择

Fig. 12 The willingness choice of construction mode about centralized residential housing for farmers 4.4\%愿意代耕代种。从县区差异看, 䀒眙县和洪 泽区农户承包地流转意愿最高，均为 $87.1 \%$, 淮安区流转意愿最低, 为 $66.4 \%$; 各县区愿 意退出耕地的占比都不高, 即使是地处主城区的清江浦区最高, 也仅为 $7.0 \%$, 涟水县 更是低至 $2.4 \%$ 。造成此种现象的原因主要是在我国农村土地 “三权” 分置的制度框架 下，农户退出承包土地不仅缺乏动力，反而在国家实施的各类农业补贴政策激励和传 统的 “有地不慌、有粮不慌” 观念影响下, 农户更倾向于保留承包土地 ${ }^{[31]}$; 另一方面, 在外出务工与本地耕种比较收益影响下, 更多农户愿意流转耕地经营权。由此可以看 出，承包地流转是主流意向，做好承包地流转是减少集中居住后耕作不便和促进集中 居住的有力措施。

表 7 愿迁农户宅基地和承包地处置意向

Table 7 Disposal intention of homestead and contracted land of the farmers with intention of centralized residence

\begin{tabular}{|c|c|c|c|c|c|c|}
\hline \multirow{2}{*}{ 指标名称 } & \multicolumn{4}{|c|}{ 承包地处置意向 } & \multicolumn{2}{|c|}{ 宅基地愿意有偿退出 } \\
\hline & 退出/\% & 流转 $/ \%$ & 代耕代种 $/ \%$ & 自己经营/\% & 农户数/户 & 占比 $/ \%$ \\
\hline 清江浦区 & 7.0 & 81.0 & 2.4 & 9.6 & 16460 & 83.2 \\
\hline 淮安区 & 5.4 & 66.4 & 11.6 & 16.5 & 66387 & 74.2 \\
\hline 淮阴区 & 5.3 & 75.0 & 3.1 & 16.5 & 55101 & 72.2 \\
\hline 洪泽区 & 5.4 & 87.1 & 1.5 & 6.0 & 18440 & 67.8 \\
\hline 涟水县 & 2.4 & 82.2 & 3.3 & 12.0 & 99613 & 78.2 \\
\hline 盱眙县 & 3.4 & 87.1 & 2.2 & 7.3 & 93437 & 96.6 \\
\hline 金湖县 & 5.4 & 84.8 & 2.9 & 6.9 & 11709 & 56.3 \\
\hline 淮安市 & 5.1 & 78.6 & 4.4 & 11.9 & 373661 & 79.2 \\
\hline
\end{tabular}

\section{3 结论与讨论}

在城乡融合发展的背景下，对农户居住空间与迁居意愿进行调查研究，是科学进行 乡村空间重构的最有效途径。本文利用淮安市统计局组织的全样本人户调查数据并结合 研究团队进行的田野调查数据，从村落和住房两个层面刻画了淮安市农户居住空间现状 特征，探究了居住空间特征形成的基本机制，从而论证了农户迁居具有客观现实需求的 论断。在此基础上，从迁居、安置和土地流转三个方面，分析了农户迁居意愿规律，回 
答了农户有无迁居意向和具体意向是什么的问题。主要研究结论如下:

（1）村民居住空间特征方面。主要特征有：淮安市自然村庄规模普遍较小，平均单 村规模为 240 余人，有接近 $20 \%$ 的自然村远离集镇在 $10 \mathrm{~km}$ 以上，超过 $50 \%$ 的自然村位于 “九靠近一滞洪” 区域内，这部分村落环境整体较差； $40 \%$ 左右村民在城乡同时拥有房 屋, 农村住房质量参差不齐, 户均面积大小不一, 楼房比例差别明显, 农房空关现象十 分普遍，乡村空心化趋势明显。影响目前空间特征形成的因素有多种，其中河网众多、 水灾频繁、部分丘陵等自然条件是早期村落分散格局形成的决定性因素。在此基础上, 就近居住地耕种、人口增长、沿交通线扩展、规划指引缺失等人文因素强化了分散格局 并促成新格局特征的出现。

（2）村民迁居意愿方面。过半农户愿意迁居集中居住，更多农户倾向于实物安置， 较低补偿标准和不便务农是农户不愿迁居的主要原因。自行去城镇购房和到自有住房是 货币安置农户的主要去向, 留村和人镇集中居住是实物安置农户的主要去向。九成以上 实物安置意向农户选择政府统建安置房。超七成农户有意有偿退出宅基地，四分之三集 中居住农户有意流转承包地。

（3）无论村民居住空间特征还是迁居意愿都存在明显的空间差异。如农户空关房率 自城区向外围呈现递增态势、县区户均房屋面积和楼房比例呈 “北高南低” 空间格局、 主城清江浦区近郊农户实物安置意向更强，远郊盱眙县农户货币安置意向更强等。空间 差异受经济发展水平、与主城区的相对位置关系、地形水系分布自然地理条件等多种因 素共同影响。但不同因素对不同居住空间层次和不同居住意愿的影响程度不同。如地形 水系分布对自然村密度和迁居意愿的影响程度就较为突出, 盯眙县就是此例证; 与城区 的距离关系，则更多影响了农户在城镇拥有住房的占比，距离城区越近的农户更愿保留 农村住房以获得可期拆迁补偿收益, 距离城区越远的农户更愿在城镇拥有住房以获得更 加便利的生活条件。

（4）村民居住空间特征与迁居意愿之间存在一定的内在关联。自然村规模小、空关 房比例高、同时拥有城乡住房农户多等居住空间特征都在不同程度上强化了农户迁居和 土地流转意愿。另外, 农户迁居意愿不仅受居住村落特征的影响, 还受居住住房特征的 影响，同时与政策推进也有直接关系。比如，农户老旧住房比例高的住房特征、控制农 村自建住房和开放城镇落户的政策等或推动或吸引了农户迁居意愿。论文研究表明推进 农民集中居住是淮安市的现实需要，也具有很好的意愿基础。村民迁居是平原农区实施 乡村振兴战略、推进新型城镇化、改善居住条件、促进土地集约利用和农村经济发展的 有效途径 ${ }^{[32]}$ 。

需要指出的是，本文虽然利用详实的全样本人户调查数据，宏观分析了淮安市村民 居住空间特征和形成机制。但基于自然村尺度的居住空间特征、形成机制、影响因素还 有待挖掘。对农户迁居意愿分析尚缺少深层次原因与影响机制研究。限于篇幅, 如何基 于研究结论提出针对性对策建议尚未涉及。另外, 淮安市全样本调查的案例研究结论与 其他平原农区的抽样调查研究结论是否吻合尚无对比。上述问题都有待进一步讨论和深 化研究。

\section{参考文献(References):}

[1] 赵楠, 冯健. 空心村村民居住生活空间特征及其优化重构: 对河南邓州市 8 个村庄的调查. 人文地理, 2016, 31(6): 
29-38. [ZHAO N, FENG J. The characteristics of villagers' living and living space in hollow villages and their optimized reconstruction: A survey of 8 villages in Dengzhou, Henan. Human Geography, 2016, 31 (6): 29-38.]

[2] 李远行. 乡土中国 VS 城市中国. 读书, 2005, (1): 126-131. [LI Y X. Native China VS Urban China. Study, 2005, (1): 126-131.]

[3] 张金明, 陈利根. 农民集中居住的意愿、影响因素及对策研究: 以江苏省江都市为例. 农村经济, 2009, (10): 17-20. [ZHANG J M, CHEN L G. Research on farmers' willingness to live in centrality, influencing factors and countermeasures: Taking Jiangdu city, Jiangsu province as an example. Rural Economy, 2009, (10): 17-20.]

[4] 孙庆忠. 离土中国与乡村文化的处境. 江海学刊, 2009, (4): 136-141. [SUN Q Z. The situation of China and rural culture in diaspora. Jianghai Academic Journal, 2009, (4): 136-141.]

[5] 马晓冬, 李全林, 沈一. 江苏省乡村聚落的形态分异及地域类型. 地理学报, 2012, 67(4): 516-525. [MA X D, LI Q L, SHEN Y. Morphological difference and regional types of rural settlements in Jiangsu province. Acta Geographica Sinica, 2012, 67(4): 516-525.]

[6] 李红波, 张小林, 吴启焰, 等. 发达地区乡村聚落空间重构的特征与机理研究: 以苏南为例. 自然资源学报, 2015, 30 (4): 591-603. [LI H B, ZHANG X L, WU Q Y, et al. Characteristics and mechanism of rural settlements spatial reconstruction in developed areas: A case study of Southern Jiangsu. Journal of Natural Resources, 2015, 30(4): 591-603.]

[7] 原野, 赵中秋, 师学义, 等. 基于乡镇地域主导功能定位的农村居民点整理策略研究. 自然资源学报, 2017, 32(12): 2089-2099. [YUAN Y, ZHAO Z Q, SHI X Y, et al. Strategy of rural residential land consolidation based on the dominate function of township. Journal of Natural Resources, 2017, 32(12): 2089-2099.]

[8] 谷晓坤, 陈百明, 代兵. 经济发达区农村居民点整理驱动力与模式: 以浙江省嵊州市为例. 自然资源学报, 2007, 22 (5): 701-708. [GU X K, CHEN B M, DAI B. The driving force and model of land consolidation of rural habitat in economically developed region: A case study of Shengzhou, Zhejiang province. Journal of Natural Resources, 2007, 22(5): 701-708.]

[9] 王勇, 李广斌. 苏南农村土地制度变迁及其居住空间转型: 以苏州为例. 城市发展研究, 2011, 18(4): 99-103. [WANG Y, LI G B. Rural land system change and residential space transformation in Southern Jiangsu: A case study of Suzhou. Urban Development Research, 2011, 18(4): 99-103.]

[10] 叶继红. 农民集中居住、身份认同及其影响因素. 内蒙古社会科学: 汉文版, 2011, 32(4): 128-133. [YE J H. Farmers' concentrated residence, identity and its influencing factors. Inner Mongolia Social Sciences: Chinese Version, 2011, 32 (4): 128-133.]

[11] 曹恒德, 王勇, 李广斌. 苏南地区农村居住发展及其模式探讨. 规划师, 2007, 23(2): 18-21. [CAO H D, WANG Y, LI G B. Rural residential development and its model in Southern Jiangsu. Planner, 2007, 23(2): 18-21.]

[12] 孙晓中. 我国农民集中居住整理模式的探讨与思考. 江西农业学报, 2010, 22(7): 192-195. [SUN X Z. Discussion and reflection on the mode of rural residential consolidation in China. Journal of Jiangxi Agriculture, 2010, 22(7): 192195.]

[13] 李本智. 基于全域城市化视角的农村集中居住实践探析: 以宁波市镇海区为例. 规划师, 2010, 26(10): 108-112. [LI B Z. An analysis of the practice of rural concentrated residence from the perspective of urbanization in the whole region: Taking Zhenhai dstrict of Ningbo city as an example. Planner, 2010, 26(10): 108-112.]

[14] 周国华, 贺艳华, 唐承丽. 论新时期农村聚居模式研究. 地理科学进展, 2010, 29(2): 186-192. [ZHOU G H, HE Y H, TANG C L. Study on the mode of rural settlement in the New Era. Progress in Geography, 2010, 29(2): 186-192.]

[15] 关小克, 张凤荣, 刘春兵, 等. 平谷区农村居民点用地的时空特征及优化布局研究. 资源科学, 2013, 35(3): 536-544. [GUAN X K, ZHANG F R, LIU C B, et al. Spatial and temporal characteristics and optimal layout of rural residential land in Pinggu dstrict. Resource Science, 2013, 35(3): 536-544.]

[16] 贺艳华, 唐承丽, 周国华, 等. 我国中部地区农村聚居现状及调控模式研究. 人文地理, 2014, 29(3): 95-102. [HE Y H, TANG C L, ZHOU G H, et al. A study on the current situation of rural settlements in Central China and its regulation mode. Human geography, 2014, 29(3): 95-102.]

[17] 郭正模. 农村居民集中居住的土地产权调整与利益主体协调: 以四川省为例. 中共四川省委省级机关党校学报, 2012, (3): 102. [GUO Z M. The adjustment of land property rights and the coordination of interest subjects in rural residents' concentrated Residence: A case study of Sichuan povince. Journal of Provincial Party School of CPC Sichuan Pro- 
vincial Committee, 2012, (3): 102.]

[18] 谢雪群, 杨钢桥, 赵微. 农地整理过程中农民利益诉求: 来自湖北省部分县市的实证研究. 中国农业资源与区划, 2014, 35(6): 45-52. [XIE X Q, YANG G Q, ZHAO W. Farmers' interest demands in the process of farmland consolidation: An empirical study from some counties and cities in Hubei povince. China's Agricultural Resources and Zoning, 2014, 35(6): 45-52.]

[19] 杨成. 农民土地财产权与农民集中居住的良性推进. 河北法学, 2014, 32(4): 70-77. [YANG C. Benign promotion of farmers' land property rights and farmers' concentrated residence. Hebei Law, 2014, 32(4): 70-77.]

[20] 阮荣平. 农村集中居住: 发生机制、发展阶段及拆迁补偿: 基于新桥镇的案例研究. 中国人口·资源与环境, 2012, 22 (2): 112-118. [RUAN R P. Rural concentrated Residence: Occurrence mechanism, development stage and compensation for demolition and relocation: A case study based on Xinqiao town. China Population, Resources and Environment, 2012, 22(2): 112-118.]

[21] 杨建云. 乡村治理视角下的农村土地综合整治研究. 中国农业资源与区划, 2014, 35(4): 20-25. [YANG J Y. Study on comprehensive improvement of rural land from the perspective of rural governance. China Agricultural Resources and Regionalization, 2014, 35(4): 20-25.]

[22] 王磊, 沈丹. 基于合约模型的农村集中居住改革机制分析. 农村经济, 2014, (7): 19-23. [WANG L, SHEN D. Analysis on the reform mechanism of rural centralized housing based on the contract model. Rural Economy, 2014, (7): 19-23.]

[23] 王勇, 李广斌. 南乡村聚落功能三次转型及其空间形态重构: 以苏州为例. 城市规划, 2011, 35(7): 54-60. [WANG Y, LI G B. Three transformations of the function of South Rural Settlement and its spatial form reconstruction: A case study of Suzhou. Urban Planning, 2011, 35(7): 54-60.]

[24] 龙花楼. 论土地整治与乡村空间重构. 地理学报, 2013, 68(8): 1019-1028. [LONG H L. On land improvement and rural space reconstruction. Acta Geographica Sinica, 2013, 68(8): 1019-1028.]

[25] 唐承丽, 贺艳华, 周国华, 等. 基于生活质量导向的乡村聚落空间优化研究. 地理学报, 2014, 69(10): 1459-1472. [TANG C L, HE Y H, ZHOU G H, et al. Study on the optimization of rural settlement space based on quality of life. Acta Geographica Sinica, 2014, 69(10): 1459-1472.]

[26] 刘继来, 刘彦随, 李裕瑞, 等. 2007-2015 年中国农村居民点用地与农村人口时空耦合关系. 自然资源学报, 2018, 33(11): 1861-1871. [LIU J L, LIU Y S, LI Y R, et al. Coupling analysis of rural residential land and rural population in China during 2007-2015. Journal of Natural Resources, 2018, 33(11): 1861-1871.]

[27] 尹旭, 李裕瑞, 袁涛, 等. 镇域经济发展与土地集约利用水平综合测度及其关联特征分析: 以江苏省 109 个抽样乡镇 为例. 自然资源学报, 2020, 35(3): 614-625. [YIN X, LI Y R, YUAN T, et al. Quantitative measurement of economic development and land use intensity and their correlation characteristics in 109 sampled towns of Jiangsu province. Journal of Natural Resources, 2020, 35(3): 614-625.]

[28] 李红波, 刘美豆, 胡晓亮, 等. 精明收缩视角下乡村人居空间变化特征及类型划分: 以江苏省常熟市为例. 地理研 究, 2020, 39(4): 939-955. [LI H B, LIU M D, HU X L, et al. Characteristics and type clasification of rural human settlement space change from Smart Decline viewpoint: A case study of Changshu city, Jiangsu province. Geographical Research, 2020, 39(4): 939-955.]

[29] 陈坤秋, 龙花楼. 中国土地市场对城乡融合发展的影响. 自然资源学报, 2019, 34(2): 221-235. [CHEN K Q, LONG H L. Impacts of land market on urban-rural integrated development in China. Journal of Natural Resources, 2019, 34 (2): 221-235.]

[30] 李传武, 吴其江. 苏北地区美丽宜居乡村建设的探讨: 以盐城市为例. 盐城师范学院学报: 人文社会科学版, 2018, 38(5): 19-23. [LI C W, WU Q J. Study on the construction of beautiful and inhabitable rural areas in Northern Jiangsu province: A case study of Yancheng. Journal of Yancheng Teachers University: Humanities \& Social Sciences Edition, 2018, 38(5): 19-23.]

[31] 李东轩, 刘平养. 三权分置改革中新型农业经营主体的政策认知及其行为响应. 自然资源学报, 2020, 35(4): 950962. [LI D X, LIU P Y. Impact of policy cognition of new agricultural entities on their behavior changes in the Three Rights Separation reform: A case study of Shanghai Qingpu. Journal of Natural Resources, 2020, 35(4): 950-962.]

[32] 李红波. 韧性理论视角下乡村聚落研究启示. 地理科学, 2020, 40(4): 556-562. [LI H B. Rural settlements research from the perspective of resilience theory. Scientia Geographica Sinica, 2020, 40(4): 556-562.] 


\title{
Villagers' living space characteristics and their willingness to relocation in plain farming area: A case study of Huai'an
}

\author{
LIU Chuan-ming ${ }^{1}$, SHANG Zheng-yong ${ }^{2}$, ZHOU Hong-Ying ${ }^{1}$, \\ WANG Cheng-xiang ${ }^{1}$, CAI An-ning ${ }^{1}$ \\ (1. School of Urban and Environment Science, Huaiyin Normal University, Huaian 223300, Jiangsu, China; \\ 2. School of Environmental Science and Engineering, Suzhou University of Science and Technology, Suzhou \\ 215009, Jiangsu, China)
}

\begin{abstract}
Using the ratio and GIS spatial analysis methods, this paper analyzes villagers' living space characteristics and their relocating willingness. All the data were obtained from the full sample survey from October to November 2018 on the 15510 natural villages and 872414 rural households in Huai'an. There are some findings as follows: (1) The rural settlements are not only scattered but also smaller on average. And what's more, there are some villages only with one family in Huai'an. Besides, most of villages are far away from the town, and nearly half of them are in the certain location which is near the water sources, or road, or railway, or situated in flood detention area, etc. These spatial characteristics are the results of a combination of the physical geographical conditions and human factors, such as the agricultural production around rural houses. (2) For the farmer's house, the proportion of the old house is higher, and $40 \%$ of rural households have their houses in both towns and villages. There is a negative correlation between the ratio of rural households which have urban houses and the distance from the village to the town center. However, the ratio of rural vacant house presents the opposite spatial pattern. (3) For villagers' willingness, $54.1 \%$ of rural households are willing to be relocated in a centralized way and most of them prefer compensation in kind. The main reasons for farmers' unwillingness to be relocated in a centralized way includes the lower compensation standards and the inconvenient farming conditions. The main destination of farmers who are willing to be settled in cash is the city, while staying in villages or in towns is other farmers' option. Nearly $90 \%$ of the farmers with willingness to relocation will choose the resettlement house which would be built by the local governments, and nearly $80 \%$ of them would return the homestead or transfer the contracted land with compensation. (4) There are obvious spatial differences in both the characteristics of villagers' living space and their willingness to relocation, which are internally related and affected by various factors.
\end{abstract}

Keywords: characteristics of living space; willingness to relocation; full sample survey; plain farming area; Huai'an 